\title{
Politics as a Profession
}

\author{
Ankit Kumar Manoj, Dinesh Sridharan, Manoj Kulandaivel \\ VIT University, Chennai Campus, Chennai, India \\ Email: ankitjames25@gmail.com
}

Received 23 February 2016; accepted 11 April 2016; published 14 April 2016

Copyright (C) 2016 by authors and Scientific Research Publishing Inc.

This work is licensed under the Creative Commons Attribution International License (CC BY).

http://creativecommons.org/licenses/by/4.0/

(c) (i) Open Access

\section{Abstract}

The proposed research is about the people's perception about "Politics as profession". This paper examines multiple case studies of people's opinion about making career in politics and further explains why most of the people are not interested in politics. By and large, people in India consider Politics as "dirt". The word "Uneducated" is directly linked with politicians in India. We have our own Indian Political history as background information for us to understand people's mentality towards politics and why most of us never want to join it. The purpose of this paper is to study the mentality of Indian parents about letting their children pursue politics as their profession. The main objective of this research is to make people understand that we can never clean the dirt by just staying away from it. Results of various surveys have been included to support the fact that people are afraid to take politics as a career. Post-Independence Era has seen kith and kin of late famous political figures that have entered politics in spite of being uneducated. Education doesn't just mean acquiring degrees from some university, but to have a sense of honor towards leading people. This paper also stresses on the fact that most people agree on having an educated politician but most of the educated people are not interested in joining politics. As we know, many Indian politicians shroud in fake degree scandal, which shows the education status of politicians in India. Our proposal signifies that people need to change their mentality about politics and join it in true professional spirit so that we can be a developed nation and present an example to the rest of the world.

\section{Keywords}

Politics, Profession, Survey, Fake Degree, Business, Career, Parent's Mentality

\section{Introduction}

$$
\text { "I never thought of politics as a profession". - Georgios A. Papandreou }
$$

As every profession has a pre-requisite, politics should also have few pre-requisite qualities, which should be 
made compulsory for anyone who would like to enter politics. Among other qualities, education should be a necessary parameter to join politics. Thus every youngster will have like-minded people to work along, removing the difference among uneducated or educated people and having a standard to maintain. As of now only people who have a prior political background are interested in making politics as their career. Many people have a question of "Why educated politicians are needed?"

There are two reasons. First, they are examples to our children. As leaders, they should set the example. An uneducated nation is doomed to fail. Secondly, a college education in a challenging subject at an accredited college teaches one how to break a complex issue into smaller problems that can be solved. Of course, not everybody needs the secondary education to be successful in business (Bill Gates, Richard Branson come to mind) Yes, $0.01 \%$ of us are super-talented at birth. But to be a leader of people in a nation that must be educated to succeed in today's increasingly complex world, they need to lead by an example.

In India, (Elliot, 2013) says politics is often regarded as a disgraced profession. That is why most of the capable and competent people are reluctant to join this profession. So making education qualification a compulsory requirement will motivate people to join politics, and thus India can have most scholar people as politicians.

\section{Review of Literature}

According to the (Sabharwal \& Lamba, 2013), who have already researched on the topic "Politics: A Business or a Profession" have given the conclusion that In India, today politics is seen neither as a mission nor a profession but purely commerce. So, it is necessary for the educated young to join politics and serve the nation. At this stage, India needs super competent leaders in politics. All our best lot becomes doctors, engineers or lawyers. So, Indian politics is in need of young, educated and talented youth who can be given the responsibility to run the country having large population.

Another author (Sundaram, 2013) speaking under the topic "Business of politics is attractive in India" says in our country we cannot take the words of any of our leaders for granted. Words have been deconstructed, promises emptied of meaning. Politics has been reduced to a mere game. It is all very straightforward: if a man`s word means nothing, it means nothing. It is folly to believe otherwise, thus explaining the status of the politics in India.

An article by (Chandra, 2013) "Professionals in politics?" beautifully states the political status of India. She asks "What's common to a banker, a dancer and a former UN under-secretary general? Answer: they are all contesting the general election in India". (Jindal, 2014) in her article titled "Is Joining Politics a Career in India?" explain about the ways for any educated youth to join politics. Courses they can study like graduation in Political science and approaches they need to follow for a better career in politics.

Thus we can understand that politics should be treated as profession and only educated people should take politics as their career. No one can guarantee that educated people would not lie but people can identify politicians with good intentions and it's in their hands to select a better leader to lead them. We do not imply that educated politicians would not lie, but it will definitely raise that standard of politics. We have an example, Arvind Kejriwal, Chief Minister of Delhi. He is a graduate from the Indian Institute of Technology and today leading Delhi with an example. We also have many other academicians like Sachin Pilot, Jyothiraditya Scindia, and Dr. Manmohan Singh, who have served India in the most optimal way they can. Dr. Singh played a major role in Economic crisis of 1991 as a Finance Minister by carrying out several structural reforms that liberalised India's economy.

\section{Methodology}

The framework of our approach is collecting data through "Random sample survey" and studying various case studies. Hence the data obtained through the survey is our primary source of data and case studies through various articles were our secondary source of data. The nature and content of the survey and articles are explained below.

Our survey is targeted towards parents and college goers, who primarily belong to IT sector. We mostly have categorized questions to get the views of the people attending the survey. As this is a randomly distributed survey, we have people attending the survey irrespective to their occupation, age and gender. We have obtained $100+$ responses for the survey. This survey covers their general opinion about the idea of "Politics as profession". We also ask people who are not interested in politics, reasons about it. Reactions of the parents have also 
been recorded when asked about their children's future in politics. Our survey also asks the people whether politicians should have a valid educational qualification.

\section{Data Analysis}

We have analyzed the primary source of data and have plotted in the pie-chart for better understanding of the reader. Below displayed Figures 1-5 shows the response of the survey.

"It has been said that politics is the second oldest profession. I have learned that it bears a striking resemblance to the first. —Ronald Reagan".

"I never thought of politics as a profession. - Georgios A. Papandreou".

\section{Key Findings}

The results of the above analysis show that people do not consider politics as profession and moreover people want the politicians to be educated. But most of the educated people think politics as dirt. It's like everyone wants a clean house, but no one wants to clean it. We have also analyzed that most of the Indian parents are not willing to send their own educated son(s)/daughter(s) to politics. Even students are not willing to join politics because they are afraid of either their future or the society, thus supporting our introduction. As pointed out earlier, we do not imply that educated politicians would not lie, but the presence of them increases the standard of the political condition. Our recommendation to make education a mandatory requirement helps leveling the ground for all people to enter into politics. Educated politicians help in inspiring the youth and changing their mind about politics. This, in turn, promotes the presence of young, educated and socially aware people enter politics. We can't force people to enter politics, but they should take initiative about their nation and enter at their will. But awareness about the political powers should be spread among people which can help them to enter politics. There is no absolute solution to this problem. Instead it can be solved gradually by spreading the awareness about politics.

Who's statement do you support?

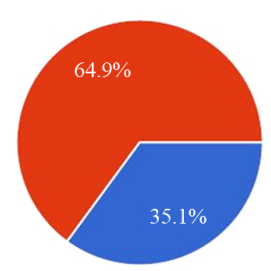

Ronald Reagan $\quad 34 \quad 35.1 \%$

Georgios A. Papandreou $63 \quad 64.9 \%$

Figure 1. People's option on Politics as profession.

If Georgios is your guy, choose your reason for supporting him.

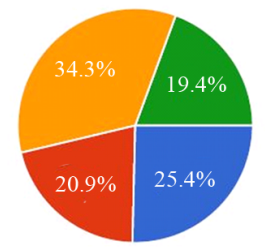

$\begin{array}{rrr}\text { Society } & 17 & 25.4 \% \\ \text { Financial issues } & 14 & 20.9 \% \\ \text { Uncertain future } & 23 & 34.3 \% \\ \text { Afraid of politics } & & 19.4 \%\end{array}$

Figure 2. Reasons for not selecting Politics as profession. 
What will be your reaction if your son/daughter wants to enter politics?
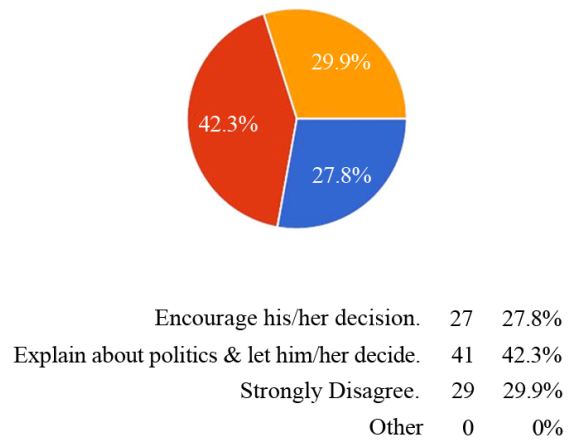

Figure 3. People's reaction to politics as profession.

Have you ever considered yourself better than any politician?

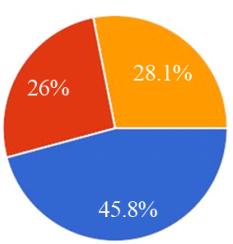

Yes $44 \quad 45.8 \%$

No $25 \quad 26 \%$

I have better jobs to do than this. $27 \quad 28.1 \%$

Figure 4. People's consideration on being better.

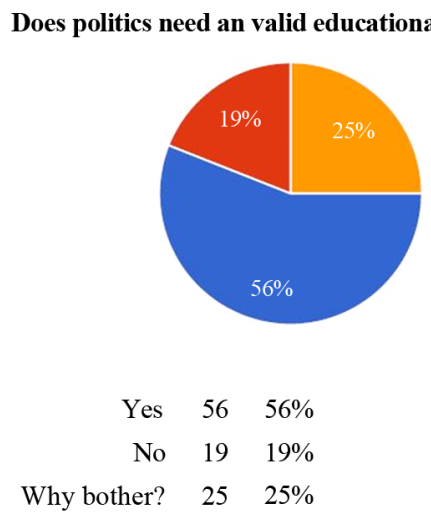

Figure 5. Education as necessary requirement in politics.

\section{Conclusion}

In our current circumstances, politics acts as a business where politicians invest their money to win a seat in assembly and make money by abusing their power. In order to change this, politics should be standardized. Educated and socially aware people should be keen on participating in politics, treating politics as a profession rather than a business. The politicians should get paid only for the amount of hard work and contributions they render and not for anything else. So for the sake of millions of lives, there is an urgent need for political system to undergo a change and make room for reforms so that only the best of the lot gets admitted to this profession. The success or failure of democracy in a country solely depends on the quality of politicians who operate in it.

Politics is a noble profession but the greed for power and fame has stained it. Because of some atrocious politicians, the integrity of the entire profession is destroyed. The image of politicians, the corrupt system, unachievable projects and slow growth have refrained the youth and competent people from entering this profes- 
sion. So we need the best and the brightest among the youth to join politics and serve the nation. Politics is not a business but a noble profession with the aim of providing service to the nation. Parents should be more supportive to their children who are interested in taking politics as a career, irrespective of society or uncertain future.

\section{References}

Chandra, R. (2013). Professionals in Politics?

Elliot, J. (2013). Politics in India Is Big Business.

Jindal, P. (2014). Is Joining Politics a Career in India? http://www.elections.in/blog/is-joining-politics-a-career-in-india/

Sabharwal, A., \& Lamba, P. (2013). Politics-A Business or a Profession? OIDA International Journal of Sustainable Development, $6,1-8$.

Sundaram, V. (2013). Business of Politics Is Attractive in India. 